\title{
Post-Soviet Nation State as a Sponsor of Construction of the Ethno-National Diaspora: Azeri's Case
}

L'État-nation postsoviétique comme soutien de la construction de la diaspora ethno-nationale : le cas azerbaïdjanais

El estado-nación postsoviético como promotor de la construcción de une diáspora etnonacional: el caso azerbaiyano

\section{Sergey Rumyansev}

\section{(2) OpenEdition}

\section{Journals}

Édition électronique

URL : https://journals.openedition.org/remi/5218

DOI : 10.4000/remi.5218

ISSN : $1777-5418$

Éditeur

Université de Poitiers

Édition imprimée

Date de publication : 1 décembre 2010

Pagination : 111-131

ISBN : 978-2-911627-56-9

ISSN : 0765-0752

Référence électronique

Sergey Rumyansev, «Post-Soviet Nation State as a Sponsor of Construction of the Ethno-National Diaspora: Azeri's Case », Revue européenne des migrations internationales [En ligne], vol. 26 - n³ | 2010 mis en ligne le 01 décembre 2013, consulté le 15 avril 2022. URL : http://journals.openedition.org/ remi/5218; DOI : https://doi.org/10.4000/remi.5218 


\title{
Post-Soviet Nation State as a Sponsor of Construction of the Ethno-National Diaspora: Azeri's Case
}

\author{
Sergey RUMYANSEV ${ }^{1}$
}

\section{INTRODUCTION}

n 18.12.2008 most Azerbaijani media circulated reports saying that the
Charter of Solidarity of Azeris of the World had finally been adopted at a session of the Coordinating Council of Azeris of the World held in Baku. In the past few years officials of various ranks have been saying that such a document is necessary and work on it is under way. It is symbolic that this session was held in Baku in the State Committee of the Azerbaijani Republic for Work with the Diaspora with the immediate participation of its director Nazim Ibrahimov. As it turned out later, journalists were somewhat too quick to report that. Only a preliminary version was adopted, work on which is still under way. However, something else is important too. The preparation of such a Charter in the capital of independent Azerbaijan is, in my view, a demonstration of how an independent state not only sponsors the process of construction of diaspora but also tries to control it. The specifics of the diaspora policy being conducted by the Azerbaijani authorities may serve as a good illustration to the thesis by Tishkov (2003: 41) which says that: "The so-called nation state and not ethnic commonality is key to diaspora formation".

The policy of constructing an Azeri ethno-national diaspora started to be intensively implemented in the early $21^{\text {st }}$ century. However, the formation of this purposeful policy was preceded by various events that demonstrated a constantly increasing interest on the part of the state in ethnic Azeris living in various countries of the world.

1 Research Fellow at the Institute of Philosophy, Sociology and Law of the National Academy of Sciences of Azerbaijan. Head of the independent social research group "Novator" (Baku). PostDoctoral research fellow at the Institute for European Ethnology, Humboldt-University Berlin; sergnovator@yandex.ru 
This article, presenting the results of the research into the process of formation of diaspora politics in Azerbaijan and also analyses the aims and specifics of the mechanisms of its implementation, has been prepared primarily on the basis of field materials collected during the implementation of a research project focused on "Diaspora Politics" in postsoviet Azerbaijan supported by the Caucasus Resource Research Center. In addition, the specifics of the influence of the state diaspora politics on the activity of expatriates is also analyzed on the basis of some projects which the author implemented with the support of various foundations, as Heinrich Böll Stiftung, Centre for Independent Social Research and Smolnyy Collegium of St Petersburg or Georg-Eckert-Instituts für Internationale Schulbuchforschung, within four years in Georgia, Russia, and Germany.

\section{RESEARCH METHODOLOGY}

The research methods were participant observation, problem-oriented semiformalized interviews, and critical discourse analyses of media materials, speeches and interviews of officials of various ranks and public figures, various official decrees... Problem-oriented semi-formalized interviews were conducted in Azerbaijan in 2008-09, with officials whose main task is to implement the diaspora project, and activists of organizations created in the course of the implementation of the diaspora project both in Azerbaijan and abroad. Another batch of material I collected using the method of participant observation of various events held in the course of the implementation of diaspora politics (conferences, meetings, etc.).

A major research method was also critical discourse analysis of a considerable body of texts which represent the official version of the meaning and results of the diaspora policy being conducted (Fairclough, 1995). These are the texts of numerous addresses by the presidents of Azerbaijan Heydar Aliyev (1993-2003) and Ilham Aliyev (2003-to date) to Azeris in emigration; numerous interviews published in Azerbaijani media in which both presidents and also officials of various ranks and activists of diaspora organizations touch upon various issues of diaspora politics' speeches by the Azerbaijani presidents, officials, intellectuals and also activists of diaspora organizations at two congresses of Azeris of the world held in Baku; news reports on the activity of "Azeris in the diaspora", and various documents which reflect the diaspora policy of Azerbaijan's political regime.

\section{“AZERI DIASPORA” AS A POLITICAL PROJECT}

First of all, I should stress that the criteria that are the most known in academic discourse, which are used to identify the phenomenon of (ethno-national) diaspora and are proposed by leading specialists, cannot by far be always relevant in the case of research into social networks and ethnic organizations of Azeris in emigration. Thus, Safran (1991) singles out six main characteristics of such diasporas: dispersion from the original "centre", to at least two "periferal" places; presence of memory or a myth about homeland; the belief that members of diaspora will not be completely accepted by new country; ideas about homeland as a place of inevitable return; commitment to support or restore homeland; and presence of group solidarity and feeling of connection to homeland. For Azeris in 
emigration such centres from where dispersion stemmed are not one but several countries with which they actually identify themselves. Integration into the host community is also not perceived unequivocally, depending on from what countries emigration came and also what country is the host one. For example, in Russia for most emigrants of the soviet wave no problems with integration arise, while work migrants of the post-soviet wave often face serous difficulties or consider their stay in Russia only as temporary. The criteria of belief in inevitable return to motherland and the feeling of connection to it are also not relevant considering the fact that there is not one such motherland but for most Iranian or Turkish Azeris the Azerbaijani Republic is not perceived as one homeland for all. Finally, group solidarity looks like the most problematic one. For Russian speaking Azeris group solidarity is defined not through ethnicity but through shared soviet socialization and language. The borders between the so-called Iranian and Turkish Azeris and natives of the Azerbaijan Republic itself also preserve their firmness.

Cohen (1996: 515) expands the range of the criteria proposed by Safran. As a result, the number of such "common features" of diaspora goes up to nine. They include: "the expansion from a homeland in a search of work, in pursuit of trade to further colonial ambitions"; " a strong ethnic group consciousness sustained over a long time and based on a sense of distinctiveness, a common history and the believe in a common fate"; "the possibility of a distinctive yet creative and enriching life in host countries with a tolerance for pluralism". Work migration is an important characteristic for describing social networks and the structure of ethnic organizations created by Azeris in emigration. But there also does not happen to be some united group consciousness in the case of the phenomenon of "Azeri diaspora" being constructed.

Another famous definition belongs to Sheffer (2003: 9-10): “An ethno-national diaspora is a social-political formation, created as a result of either voluntary or forced migration, whose members regard themselves as of the same ethno-national origin and who permanently reside as minorities in one or several host countries. Members of such entities maintain regular or occasional contacts with what they regard as their homelands and with individuals and groups of the same background residing in other host countries. Based on aggregate decisions to settle permanently in host countries, but to maintain a common identity, diasporas identify as such, showing solidarity with their group and their entire nation, and they organize and are active in the cultural, social, economic, and political spheres".

Diaspora is also considered as a real, joint group, which once formed and then remains practically unchanged. These definitions do not aim to try to see the phenomenon of diaspora as a process. A process in the course of which there can be ups and downs in the political and/or any other activity. The republic gained independence in the course of the Armenian-Azerbaijani conflict over Karabakh (1988-94) which, as it quite often happens, caused a mobilization of ethnic Azeris who were living in Germany, Russia or USA at the time and sought to give support to their political homeland (Demmers, 2005). As early as the early 1900 s, the country of origin tried with a varying degree of intensity to use this activity which spontaneously emerged and aimed to support the political motherland. At the same time, the authorities of their political homeland also made efforts to mobilize ethnic Azeris around the world, confirming in this way the thesis that "The formation of 
diaspora is therefore an issue of social mobilization" (Sökefeld, 2006: 268). Time happens when the idea to establish trans-state business networks between the host country and the country of origin acquires special popularity, like it has been happening in recent years. However, these splashes of interest are normally temporary and often fade out in the second or third generation of emigrants' descendants. Cohen (1996: 515) himself too stresses that the criteria he singles out should be viewed as "one of 'common features', to indicate that no diaspora will manifest all features".

The main problem of all definitions cited is that they originate from the idea of the existence of various diasporas as real communities whose members are consolidated and invariably active in their relations with homeland. Or, as Tishkov (2003: 440) notes, "the main weakness in the interpretation of the historical phenomenon of diaspora in modern literature is the essentialist reification of diaspora as collective bodies ('stable aggregates'), what is more, not only as statistical multitudes but also as culturally homogenous groups, which with a more sensitive analysis is almost impossible to establish". And even if some of the criteria suggested by Cohen, Safran or Sheffer can be applied when describing social networks and structure of ethnic organizations created by Azeris in emigration, all definitions proposed do not in any way explain the diaspora policy of the Azerbaijani political regime. It is this policy of the regime that runs the country which is described as the political motherland for all Azeris or, to be exact, as the specifics of the mechanisms of its implementation, which to a considerable extent identifies the specifics of the phenomenon which the authorities describe as "Azeri diaspora".

In this connection, I see as the most constructive the approach proposed by Brubaker (2005: 13) who notes that "rather than speak of 'a diaspora' or 'the diaspora' as an entity, a bounded group, an ethnodemographic or ethnocultural fact, it may be more fruitful, and certainly more precise, to speak of diasporic stances, projects, claims, idioms, practices, and so on". Based on this position, we can analyze not only mechanisms of implementation of also the "styles" of the political project of the Azerbaijani authorities and the activities of ethnic activists in emigration which are aimed at constructing an ethno-national "Azeri diaspora". These "styles", largely identified, as the background of those who created and are implementing this project, give special specific features to the networks of emigrants and the organizational structure that seek to unite all Azeris in host countries into some sort of a united community.

It is excessive to develop a discussion about the inflation of the instrumental meaning of the term "diaspora" itself which has been more frequently used in relation to numerous emigrants' social networks and communities that appeared in the $20^{\text {th }}$ century, for very different reasons, in different countries of the world. However, we share the position of Brubaker (2005: 3) who stresses: "If everyone is Diasporic, then no one is distinctively so. The term loses its discriminating power - its ability to pick out phenomena, to make distinctions. The universalization of diaspora, paradoxically, means the disappearance of diaspora".

Therefore, hereinafter the mention of the terms "diaspora" and "diaspora politics" in the text will only reflect the official discourse, which is constructed by the political regime in Azerbaijan and within the space of which in host countries Azeris are repre- 
sented as a homogenous and joint ethno-national community, "diaspora". Since the early 1990s this term has been widely and habitually used in Azerbaijan (like, actually, by ethnic activists in emigration too) by officials, all possible sorts of experts (political analysts, sociologists, historians, etc.), journalists and regular people.

The authorities in the political homeland (Azerbaijani Republic, AR) do not put in the notion "Azeri diaspora" the common characteristics of similar communities as having "catastrophic origin and uncomfortable outcome" (Cohen, 1996: 515). The main criterion is the way the authorities in the homeland describe ethnic Azeris who have for various reasons ended up outside their official nation state. Azerbaijan "becomes an external national "homeland" where "political elites construe certain residents and citizens of other states as co-nationals, as fellow members of a single transborder nation, and they assert that this shared nationhood makes the state responsible, in some sense, not only for its own citizens but also for ethnic co-nationals who live in other states and possess other citizenships" (Brubaker, 1996: 5). Such an attitude from the authorities covers all ethnic Azeris who either permanently or temporarily (including even students) reside abroad.

\section{CRITERIA FOR ASCRIBING ONE TO "DIASPORA"}

The criteria that can be used to identify who should be described as Azeri are given in Article 1 of the current version of the "Charter of Solidarity of Azeris of the World" headlined "The Ethno-Social and Philosophical Notion 'Azeri", in which "Azeris are united by such ethnographic-cultural features as language, religion and spirituality". The structure of the notion of Azeri includes: first, Azeris themselves (here the authors apparently mean ethnic Azeris or, as it became commonplace to think in the post-soviet period, Azeri Turks), second, "Ethnic minorities who live in Azerbaijan and have merged with Azeris of Turkic origin"; and finally, in the spirit of modern liberalism, anyone that regards themselves as Azeri.

On the whole, the approach to the definition of "nation" is essentialist in nature. At the same time, the Charter reproduces, to a considerable extent, ideas that have already been laid out in the law "On state policy towards Azeris living abroad". This law was endorsed by Heydar Aliyev on 27 December 2002, a year after the holding of the First Congress of Azeris of the World (November 2001). Following the spirit of the law, the authors of the Charter point out that former (or those who have not lost that status) citizens of the Azerbaijani SSR or independent Azerbaijan who "think of themselves as Azeris in terms of their ethnic, linguistic and/or historical ties" are considered to be Azeris living abroad.

Authors of the Charter write that "the fact that many Azeris are citizens of various states must not prevent their ethnic unification". The first (and the most important) reason why dispersion should not be an obstacle for unity is the existence of the independent Azerbaijani Republic. Other criteria are "Historical motherland etched in the ethnic memory of the people", then follow traditions, language, religion, ethno-social outlook, ethno-cultural system of rules, ideology of "Azerbaijanizm" (Azəbaycançılıq i.e. Azerbaijani nationalism), and finally the fact that there is a "national leader" in the shape 
of Heydar Aliyev who declares: "I have always been proud of being an Azerbaijani!" that are described as some ideal of attitude to the imaginary community of Azeris. The charter calls for following such a manifestation of particular significance of ethnicity. "Dear compatriot! Be proud of the fact that you're a child, descendant of this ancient land, a representative of a nation with a glorious history! Be proud of being an Azerbaijani!".

During the development of the text, recommendations, feedback and proposals from various organizations, including diaspora ones, were used as a basis. This is not only about ethnic organizations of Azeris, as the Society of Azeris of Latvia, the Council of Azeris of America, the Society of Azeris of Mainz, the Azerbaijani House of Belgium... Headlines were also received from the Turkish diaspora organization Community of Turks of Berlin. However, in this case too the political regime exercised total control over the procedure of the putting together of the charter: headlines came in from the department of public and political issues under the presidential Administration, the country's Foreign Ministry, the State Committee for Work with Religious Bodies, and, finally, the Research Institute for Philosophy and Political and Legal Studies of the Azerbaijani Academy of Sciences.

The working group that put together the text of the Charter includes only specialists in humanities (a total of 19 people) that work in various universities of the country and research institutes of the Academy of Sciences. Based on criteria of singling out Azeris and modern ideology of Azerbaijani nationalism, specialists also provide a definition for "diaspora" which "a united and inseparable part of the Azerbaijani people that lives outside its historical Motherland". In this case, this is about quite a common definition that implies, as Tishkov put it, a must-presence of such a "conditional category" as motherland.

\section{IMAGINARY STATISTICS}

At the same time, the description of "historical motherland" of all Azeris contains also a statistical discourse in the context of which Azeris become a large ethnic community whose members live in 70 countries. At the same time, belief in the presence of a "historical motherland" for everyone and imaginary statistics of the number of residents in host countries become important elements of constructing the image of a large and consolidated "Azeri diaspora". In the context of the diaspora discourse it is common to believe that it is the considerable number of residents said to be a part of the ethno-national diaspora that largely determines the level of the influence of the community in one or another country. The constructed official statistics of the number of ethnic Azeris looks somewhat contradictory. On the official (governmental) site dedicated to the $1^{\text {st }}$ Congress of Azeris of the World, which was held in Baku on November 2001, general information has been posted dedicated to the "Azeri diaspora"2. In addition to everything else, it says that "According to rough estimates, about 45 million Azeris live in 70 countries of the world, including Azerbaijan, today".

$2 \mathrm{http://www.diaspora.az/qurultay/d-ru.htm}$ 
By the time the $2^{\text {nd }}$ Congress of Azeris of the World was to be held (March 2006) the State Committee for Work with Azeris Abroad prepared a documentary with the eloquent title "We are a 50 millions strong people". Ever since, this film, not the only of this kind, has been one of the mandatorily viewed ones at various official events linked to the implementation of the diaspora project. The important ideological significance of such films for the ruling regime in the country becomes clear if one remembers that the opening of this $2^{\text {nd }}$ Congress started with the demonstration of another one of them, entitled "We, Azeris". This film aims to propagate within the "diaspora" the activities of the former president (and the father of the incumbent), Heydar Aliyev.

President Ilham Aliyev's speech actually started with the mention that "Today a wonderful film has been screened here. We once again recalled the beautiful moments when at the initiative of the national leader of our people, Heydar Aliyev, five years ago took place the 1st Congress of Azeris of the World which played an exceptional role in the modern history of Azerbaijan" . A series of such films was prepared specially to present the ideology of the official diaspora project to Azeris in emigration. Although these films are not some kind of secret information, in Azerbaijan itself they are practically inaccessible for viewing. That is to say, this propagandist material is not aimed for domestic audiences.

Considering the special significance that is attached to statistics, it is natural that the compilers of the Charter dwelled upon the issue of the number of ethnic Azeris. This text says there are as many as over $50 \mathrm{~m}$ Azeris. According to "rough estimates" by the compilers, four out of five Azeris live in their "historical motherland" and only one out of five outside it.

All the official ethnic Azeris that live outside their "historical motherland" in the context of diaspora discourse become a united and homogenous ethno-national diaspora, regardless of whether they previously were (or currently are) citizens of the Azerbaijani Republic itself, Georgia, Iran, or Turkey. The mention of these countries is no coincidence: outside the Azerbaijani Republic itself, Azeris populate precisely these three countries and it is this populated territory that is described as "historical motherland" in the context of Azerbaijani nationalism. Therefore, considering the specifics of the political areal populated by ethnic Azeris, the same Charter pays great attention precisely to these issues. At the same time, although explicitly Iran, Georgia and Turkey are not mentioned, it is these territories populated by ethnic Azeris that the authors of the Charter refer to.

Outside the "historical motherland", special importance is attached to "Azeri diasporas" in those countries which, in the opinion of the authorities in Azerbaijan, play a leading role in the world political arena. In the CIS that is the Russian Federation where the largest number of Azeris live who for various reasons ended up in this country. Among the EU countries, special significance is attached to Germany where currently the largest number of Azeris who migrated to Europe lives. In addition, in this case, special hopes are pinned on the establishment of close contact with Turkey too. Finally, special significance

3 Azerbaijani president's speech at the $2^{\text {nd }}$ Congress of Azeris of the World, in Bakinskiy Rabochiy, $\mathrm{n}^{\circ} 48,03.17 .2006$. 
is attached to the activities of the "diaspora" in the USA as the only super power of the modern world. Besides, the increasingly more active embassies of Azerbaijan in Russia, Germany and USA, also very active Consul-general in Los Angeles, are acting as coordination centers providing for cooperation between diaspora organizations in these countries and the authorities of the political motherland.

Unification of all these Azeris who have for a variety of reasons and at different times found themselves outside their country of origin (i.e. Azerbaijan itself, Iran, Turkey or Georgia), becomes possible only within the context of diaspora discourse and the practice of bureaucratization of emigrants' social networks.

\section{THE DISCOURSE AND BUREAUCRATIC PRACTICES OF CONSTRUCTION OF DIASPORA}

The mechanisms of the implementation of the political project for the construction of diaspora come down to two major and inter-related practices.

\section{The First is Discourse Practice}

"Via the discourse practice, some kind of construction of diaspora as a group occurs" (Tishkov, 2003: 180). Via discourse practice, all those whom ethnic activists and officials in the political motherland identify as ethnic Azeris are viewed as "Azeri diaspora", quite often using statistics as a habitual "institution of power" (Anderson, 1998: 163). At that, the extent of the intensiveness of daily ties and contacts between actors, who are ascriptively viewed as a diaspora community of Azeris, no solidarity of their political or any other interests is discussed. In the context of, as Billig (1995: 102) put it, "the rhetorical clichés of political discourse" almost all Azeris in all situations are a homogenous and united community (ethno-national diaspora) that is invariably loyal to the construct of ideal political motherland-nation.

Yes, on the one hand, said the previous Azerbaijani President Heydar Aliyev in his speech at the $1^{\text {st }}$ Congress of Azeris of the World ${ }^{4}$, "We believe that every one of the Azeris living in various countries have settled their life in that country in the way they want. Every one of them is a citizen of that country, and must live by its laws and rules and go along the path selected". However, this loyalty to the host country "must" (this imperative tone is also present in the text of the Charter) be accompanied also by loyalty towards the political motherland, and "Azeris living outside Azerbaijan must today maintain closer ties with independent Azerbaijan".

However, preliminary observations make it possible to assume that the daily routine of many statistical Azeris living in Russia, Germany or USA, is to a much larger extent determined by how they ended up in one of this countries or from what country they emigrated, and not by the intensiveness of contacts with other representatives of the

$4 \mathrm{http}: / /$ www.diaspora.az/qurultay/speech-ru.htm 
imaginary community or ties with their official homeland and intensive activities in the cultural and other spheres.

The routine, practically daily reminder in the media about the activities of the "Azeri diaspora", constant interviews with ethnic activists, officials and various sorts of public figures talking about their successes in the implementation of the project for the construction of diaspora, form the discursive effect of truth within the context of which "diaspora" acquires the features of a true, large, joint and homogenous community united by common goals. Effectively, "With the help of the word 'diaspora', 'communities', etc., a desirable image of reality, which is presented as this very reality, is created" (Kosmarskaya, 2002: 114). At the same time, the very realism of such social group as nation, the giving to it of essentialist characteristics, and also the idea of inevitable solidarity of all actors ascribed to it do not contradict the simple "common sense" of those carriers of power and intellectuals who implement the diaspora project. All of them (both presidents, the head of the State Committee for Work with the Diaspora, most officials of various ranks, intellectuals working on the text of the Charter, etc) socialized in the Soviet times, when institutionalized ethnicity was a major basic characteristic of any USSR citizen. In accordance with Brubaker (1994), Malakhov (2007: 50) notes, "the ascribed 'ethnicity' (i.e. identified by the authorities and not by the self-consciousness of individuals) was interiorized by people and gradually turned from an external identifier into part of (self)-identity. Hence originated such peculiarity of political thinking as methodological ethnocentrism - view of society as a conglomerate of 'ethnoses' ('peoples'). This type of thinking is today shared both by mass consciousness and a considerable part of intellectual and political elites".

\section{The Second is the Bureaucratic Practice of the Production of a Hierarchically Structured and Co-subordinated Organization Structure}

A rapid bureaucratization of social networks of Azeris in the world occurs, as a result of which an organizational structure of diaspora is constructed. Here I mean a process where increasingly more new diaspora organizational structures are produced "including transnational ethnic and hometown associations" (Henry, et al., 2004: 841) within the context of actualization of contacts with political homeland. With an ever increasing intensiveness, during almost all post-Soviet years ethnic activists have been making attempts, as Benedict Anderson put it, with the support of the state machine of the country of origin, to construct an ethno-national Azeri diaspora in Russia, EU countries, USA or any other states as collective subjectivity (Anderson, 1998). As a result, more and more often ethnic Azeris, who temporarily or constantly live in CIS and EU countries, USA or Canada and so on are referred to as a homogenous group (Brubaker, 2002: 163-167) - the "Azeri diaspora".

Within this context diaspora politics contains certain contradictions. On the one hand, the policy of unification with the Turkish diaspora is declared, which, in the opinion of Safran (1991: 91), can, with a certain degree of proximity, be described as an ideal type of diaspora. It is this element of the diaspora politics that can be especially topical for the community of Azeris in Germany and USA, but not in Russia. On the other hand, 
borders between ethnic Azeris from Turkey (so-called Turkish Azeris) and actual Turks are constructed.

At the same time, despite the active attempts by the Azerbaijani authorities to actualize the ethnic identity of emigrants and step up their contacts with their "official motherland", "Identity, in principle, is a runny and mobile substance, therefore the space of choice for members of the diaspora here is sufficiently big" (Kolsto, 2001: 7). Eventually, despite the active diaspora policy of the Azerbaijani regime, the entire activity immediately in emigration comes down to the activity of a number of ethnic activists who for a variety of reasons participate in the work of organizations that they themselves created. In the meantime, the activity of the relatively few ethnic activists and organizations most often does not have practically any influence on daily practices ascribed to "diaspora", according to Brubaker (2005: 13), "the majority who do not adopt a diasporic stance and are not committed to the Diasporic project". We should stress that contacts with ethnic organizations, and, moreover, immediate participation in their work is topical, to very varying degrees, only for a handful of emigrants.

However, such a low activity in emigration is not an obstacle for the increasingly numerous ethnic organizations to become a major element of the discourse within the space of which constructs of the ethno-national "Diaspora" of Azeris acquire the features of a real consolidated community. The demonstration of the process of continuous production of ethnic organizations that almost invariably become partners for the authorities, as a system-forming element of constructing an ethno-national diaspora, is present in speeches, statements and interviews of politicians. As a result of the implementation of the Diaspora-Building project by mid-2007, in the words of the "Minister of Diaspora of Azerbaijan Mr. Ibrahimov"5, "more than 300 Azeri communities are operating in most of the countries of the world, and the process of establishment of diaspora organizations is continuing presently too" .

The logic of multiplication of the quantity of organizations as a symptom of success of diaspora-building can be understood primarily proceeding from the premises that there had almost not been these kinds of structures by the moment Azerbaijan gained independence in $1991^{7}$. Their current ever-increasing number is becoming a symbol of the strengthening of the positions of independent Azerbaijan in the world. At that, certainly, one should not put the growth of the number of officially registered ethnic organizations down only to the efforts of the authorities in the official homeland. The spread of the disposition for building these kinds of structures was caused by the very emergence of an independent political homeland, without any deliberate policy on the part of the

5 A female informant, about 45, in Berlin gave this apt definition to the status of Nazim Ibrahimov, head of the State Committee on Relations with Azeris Living Abroad.

6 Fifth anniversary of the establishment of the State Committee on Relations with Azeris Living Abroad. Available at: http://www.azinba.az/news_detail.php?news_id=5397

7 However, small organizations did exist before. For example, 2008 marked the $50^{\text {th }}$ anniversary of the above-mentioned "Community of Azeris of America", which is led by Tomris Azeri. But it would be an absolute exaggeration to talk about any serious movement or policy of construction of ethno-national diaspora back in the Soviet period. 
authorities, while some revival in their activities coincided with the transformation of the Karabakh conflict into a full-scale war between Azerbaijan and Armenia.

These and many other ethnic organizations carry out the function of presenting the ever-growing organization and activities of ethnic "Diaspora" within the discourse. However, according to my observations, in the emigration the numerous numbers of ethnic organizations, on the contrary, have to do with the absence of a real unity of goals and interests among the residents. At the same time, a fast growth of their number shows the specificity of the policy of influence on emigrants, on the part of the authorities of the official homeland. The bureaucratic system of the authorities consolidated within the space of the political homeland can build its relations only with a certain structure (envisaging a certain hierarchy) consisting of ethnic organizations registered in one or another host country. The realization of contacts, establishment, as it is declared, of dialogue and interaction between the authorities and the "Diaspora" becomes possible only through relations with official organizations which assume the task of presenting all Azeris abroad. These organizations increasingly more often arise in response to the expectations of the authorities of the official homeland, while ethnic activists creating them in host countries, increasingly more often seek to implement transnational economic projects through these contacts. The authorities, certainly, seek to choose partners, and through the discourse practice officially endorses their status, confirming their right to represent the entire community in one or another part of the world. This response (from the political homeland and ethnic activists in emigration) aspiration to produce a sort of a strictly hierarchised structure of the "Diaspora" is based on the fact that common political, cultural and economic interests are shared, to this or other extent. Starting with organizations that apparently represent communities of cities (for instance, "Mainz-Azerbaijan"), and then communities of one or another EU country (for instance, "the Advisory Council of Azeri diaspora organizations", operating in Germany, was founded in Mainz in July 2007). These organizations are increasingly more often divided into youth ones and not. All these structures operate with support from and/or under monitoring by the Azerbaijani Embassy in Germany. Then follows a body apparently uniting all Azeris of Europe (for instance, the Congress of European Azeris) and above them is an organization that apparently represents all Azeris of the world and coordinates their activities - "Coordinating Council of Azeris of the World".

This structure, which is uniform from local organizations up to those that represent all ethnic communities, and which is constructed by the principle of state vertical of power, seems to be simple, clear, transparent and convenient to control. At the head of this structure there is "a minister for the Diaspora", already subordinated, directly, to the pan-Azeri President. The latter describes the present stage of the implementation of the project as follows: "We are now finishing the structuring of all Diaspora organizations of Azeris living abroad. We have held the World Congress of Azeris two times. At least $50 \mathrm{~m}$ Azeris live in the world. Certainly, the strong Azerbaijani state should provide support to all our compatriots. At the same time, strong Diaspora organizations help assert our national interest. Until recently, some five to six years ago, these organizations operated practically on a voluntary basis. In this connection, by the decision of our national leader Heydar Aliyev, the State Committee for Work with Azeris Living Abroad was created. It deals with problems facing the Diaspora only. At present, these organizations are struc- 
tured in every country. We have recently opened more than 30 embassies in different countries, and now their number has increase to more than 50 in the world. All embassies and Diaspora organizations in those or other countries operate together. It turns out that this is a two-way street: we render them assistance, and they, in turn, help their country".

Thus, within the space of the diaspora discourse and the related practice of bureaucratization of emigrants' social networks, Azeris in various countries of the world become a true united group - "diaspora". Within the space of the diaspora discourse, emigrants who have for a variety of reasons found themselves in different countries of the world, including Azeris, citizens of different countries unite and acquire features of a homogenous joint group. In the meantime, description, in the context of the diaspora discourse, of the image of the joint and large diaspora penetrated and controlled by the united and hierarchically co-subordinated bureaucratic structure of ethnic organizations is a visible confirmation of the real existence of a large diaspora community of Azeris.

\section{THE GOALS OF THE DIASPORA POLITICS}

The goals of the diaspora politics declared by authorities and diaspora activists that actively participate in its implementation can apparently be very different. This is for example an intensification of the participation of diaspora representatives in an as wide promotion as possible of official Azerbaijani position in the Karabakh conflict. In this context, "Diaspora politics may be more a result of conflict than its cause" (King and Melvin, 1999-2000: 137). Resolving the Karabakh conflict assumes, for example, a certain "struggle with world Armenians", "which", in the opinion of President Ilham Aliyev, "We [i.e. Azeris of all the world] should oppose with unity and force". He said these words in his speech on the occasion of the opening of "The XI Congress of Friendship and Brotherhood of Turkic States and Communities", which was held in Baku in November 2007. The constant mention of the Armenian Diaspora demonstrates the fact that the official project for the construction of "Azeri diaspora" is very largely built on stereotypes about the Armenian Diaspora.

In addition, the current political regime seeks to use ethnic (diaspora) organizations and networks to spread the official national ideology of "Azebaijanizm", adopted in the Azerbaijani Republic, among emigrants. This is about the post-Soviet version of the "ethnogeny" of Azeri Turks, history of statehood, and the image of "historical enemies" that occupy an important place in the post-Soviet version of history. Ethnic activists and organizations are, apparently, more intensively joining this activity, providing opportunities for emissaries from their political homeland to deliver lectures, spread literature (of particular importance here are history textbooks, including those developed for secondary schools), to hold various exhibitions or collective events.

The tangle of opinions, interests and expectations of intellectuals, all sorts of experts and politicians concerning Azeris abroad, is also shaped depending on the foreign

8 Exclusive interview of Azerbaijani President Ilham Aliyev to Kazinform's correspondent in Baku. Available at: http://www.day.az/news/politics/88011.html 
policy preferences of the authorities and politicians in official homeland. Thus, an active involvement of the "Azeri diaspora" is presumed in the campaign for the recognition of injustice in the assessment of the events of 1915 in Anatolia, namely of the genocide claims put forward to Turkey, present-day major ally of Azerbaijan. The declared foreign policy priorities acquire a special meaning too (for example, orientation towards participation in European and Euro-Atlantic structures). It is within these contexts that an increasing popularity is gained annually by the ideas that present Azeris in Germany, the USA, Russia, or in any other country that has weight in world politics, as a certain significant political resource which the authority in the country of origin can and should use to achieve certain political preferences. On the whole, at the level of declarations, this primarily means advertising "democratic transformations" carried out by the ruling regime in Azerbaijan, presenting the "young" Azerbaijani community abroad.

Special place in the diaspora policy is given to the holding of collective events on the occasion of various memorable dates. These events are described in the context of the diaspora discourse as facts that confirm the invariable unity of the large community of Azeris of the world. Collective events in the "diaspora" that are of interest to the Azerbaijani regime, are also held, in addition to marking events of the Armenian-Azerbaijani confrontation, on the occasion of symbolic dates of the establishment of independent Azerbaijan, and are also connected with the propagation of the activities of the former president (and the father of the incumbent), Heydar Aliyev.

The conflict over control of the Karabakh region (1988-94) resulted to the Azerbaijani-Armenian confrontation becoming retrospectively translated onto many events that had occurred much longer before it. These include the events of 1918 in Baku, when pogroms took place in Muslim neighbourhoods in the city as a result of a political confrontation between Bolsheviks, who had attracted to their side troops controlled by Armenian nationalists (Dashnaks), and Musavatists (Turkic nationalists). As a result, about 10,000 were killed. This event has been referred to in the post-soviet period. After Heydar Aliyev's decree of 1996, the events of March 1918 started to be interpreted as genocide. Currently the authorities call on ethnic activists to hold collective events on 31 March. The idea of this genocide of Azeris also becomes some kind of a countertheory against the Armenian genocide in Anatolia in 1915-18. The Azerbaijani authorities actively lobby the idea of the need to back the Turkish authorities and Turkish diaspora organizations that deny the genocide. Among other events, the events of 20 January 1990, when, according to official reports, up to 132 people were killed when soviet reports were deployed to Baku which the USSR authorities were practically not in control of, have acquired the greatest significance; and ethnic cleansing in the town of Xocali (events of the Karabakh war). I should say that far fewer emigrants participate in these events than in events held on the occasion of holidays.

The holidays that have been established in the post-soviet period and are backed by the Azerbaijani authorities can be said to include the Day of the Solidarity of Azeris of the World (31 December), Day of the Republic, which is considered to be the day of the revival of Azerbaijani statehood (28 May), and, to a lesser degree, Independence Day (18 October). 
Finally, collective events (concerts, conferences, rallies, etc.) linked with events of the policy to commemorate the activities of the previous president gain an everincreasing significance. After his death in 2003, he, largely similarly to Atatürk, becomes in the context of the official discourse the symbolic "national leader" (ideal politician and Azerbaijani) for the entire nation. Therefore, not only anniversaries but even simply the days he was born and passed away, and dates linked to his rule ("Day of Salvation of the Nation", etc.) are hailed to be marked within the diaspora.

The implementation of all these goals, in the authorities' opinion, implies creation of an Azeri political lobby in the host countries, primarily, in the modern world's leading political and economic centres (USA, EU, and in a way Russia). Therefore, the policy of construction of "Azeri diaspora" actually aims to create own no less united and joint ethnic community -Diasporic "Lobby" which would be able to oppose the considerable Armenian Lobby with a no less serious political power. The aim of such policy of ethnic activists in emigration may be described by a phrase by the ex-president of the Congress of European Azeris (CEA) Bahaddin Kaya: "Now, in my opinion, the main task of the Diasporic movement must be to create a powerful propagandistic Turkic Lobby abroad".

And here, special interest arises in cooperation with the Jewish diaspora. Ethnic Jews, natives of Azerbaijan, are perceived by the authorities as a very important resource for creating a political lobby. In the project of construction of the ethno-national "Azeri diaspora", this disposition for cooperation with the Jewish Diaspora (and not only Turkish diaspora) is being increasingly often proclaimed by the Azerbaijani authorities too. Thus, for instance, Nazim Ibrahimov, said in July 2007: "The State Committee has long been seeking a key to creating an Azeri diaspora organization in US states like California, where traditionally the Armenian lobby is powerful. And we've found such a key. The Jewish diaspora, operating here, is ready to help us organize our diaspora"10.

Here are views on cooperation from a European perspective by Natig Ahamirov, the President of the Congress of European Azeris (CEA): "Azeri communities closely cooperate with Jewish diaspora organizations. The CEA is trying to improve its work in this sphere. We consider that we can use the potential of Jewish communities in those countries where Azeri communities under-operate and have limited opportunities to influence social and political processes. The centuries-old friendship between our peoples gives us wide opportunities for this cooperation. We just need to efficiently take advantage of this potential. Recently, the Azerbaijan-Israel international Association was established in Israel. The CEA is planning to establish close relations with this structure. In one word, we are thinking about joining our efforts in all spheres"11.

The active participation of ethnic Jews in the work of the Azerbaijan community (consisting of, in a wide sense, all natives of Azerbaijan) is not something out of the ordinary and has to do with a circumstance which Safran (2003: 390) well describes as "the persistence of fraternal societies based on common local background" as Niznir

9 See: http://www.azerizv.az/article.php?id=5698

10 See: http://www.day.az/news/politics/85680.html

11 See: $\mathrm{http}: / /$ news.trend.az/index.shtml?show=news\&newsid=953305\&lang=RU 
(2003) does too. This background helps preserve the Jewish "subcommunities" in Israel, determined by their country of origin - "Anglo-Saxons", "Easterners", "Russian" and others. In the case of ethnic Jews, natives of Azerbaijan, these are Mountain Jews from Quba town and Baku city, and Ashkenazi Jews from Baku.

\section{MAIN EVENTS OF DIASPORA PROJECT}

As already indicated above, it was Heydar Aliyev who implemented the project for constructing an "Azeri diaspora". In the post-soviet period, he was Azerbaijan's president from 1993 to $2003^{12}$. The many years of being in power made him, as Bourdieu (2007: 84) put it, "a trusted person who had the power to "form a group". It was his activities, back in the years when the USSR existed, that largely led to the establishment in Russia of an intellectual layer from among ethnic Azeris, who became ethnic activists when the USSR collapsed. Much later on, Heydar Aliyev said in his speeches that his had been conscious of his actions. However, he never claimed that he could foresee the collapse of the USSR and that Azeris would turn into "diaspora".

Thus, speaking at the Founding Assembly of the "All-Russian Azeri Congress" (AAC) on 22 June 2000, he stated that: "previously, always, when I worked in Azerbaijan, I said, and this was my firm belief both then and today, that no people can develop at the pace of the entire world community, the entire world system if it isolate itself in the space boundaries of its territory. I.e. I have always opposed the feeling of national restriction"13. Such a clear-cut position was, probably, conditioned by his personal experience. Heydar Aliyev himself studied for some time in Leningrad, and spent a long time living and working as one of the USSR leaders in Moscow and knew well that in a host of specialities a high level of education as a major factor of mobility and demand in the modern world is often possible only if one receives education outside Azerbaijan. Education in a number of specialities in the Azerbaijani SSR was not accessible in principle. "Guided by these principles, when I worked as Azerbaijan leader in the 1970s, and up until the end of 1982, then I sometimes even administratively made sure that our young people, youth, went to other republics of the Soviet Union to receive education. Back then, we did not have opportunities other than the Soviet Union, i.e. within the Soviet Union. Azerbaijan was the only republic which managed to achieve major privileges in this regard. From 1970 on, I set a task to send many Azeris outside Azerbaijan, primarily to Russia, primarily to Moscow, Leningrad, and other major centres for higher education, centres for science, centres for culture" (Bakinskiy Rabochiy, 28 June, 2000).

In addition, Heydar Aliyev himself, due to circumstances, took part in the first collective event of Azeris in Russia in 1990. That was "January 1990" - a protest against the deployment of Soviet troops to Baku on the night of 19-20 January 1990. According

12 The current president also points to this: "the idea of organizing and the initiative for consolidation of Azeris of the world were put forward by the great leader Heydar Aliyev", in Bakinskiy Rabochiy, 28 June 2000.

13 Azerbaijani President Heydar Aliyev's speech at the founding assembly of the all-Russian congress of Azeris in Moscow, in Bakinskiy Rabochiy, 28 June 2000. 
to my observations, by the end of the 1980 s, although no-one was yet expecting the disintegration of the Soviet Union, which was coming in the not distant future, Azeris (often under the influence of policy conducted by Russian officials who sponsored the production of ethnic organizations) started gradually recognising themselves as sort of a community that had found itself outside their country of origin. The January 1990 events in Baku, when 132 people were killed and many injured, actualized the feeling of being in emigration. Heydar Aliyev was the central figure among those publicly expressed their protest against the actions of the soviet leadership. Possibly, precisely these events reaffirmed his belief that the networks of ethnic Azeris not only in Russia might become a significant resource that could be mobilized to support their country of origin.

The first important step of the then planned diaspora policy was a decree by $\mathrm{H}$. Aliyev declaring 31 December to be the Day of Solidarity of Azeris of the World. It is remarkable that this decree was adopted even before 16 December 1991, i.e. when he held the post of chairman of the Supreme Assembly of the Naxcivan Autonomous Republic ${ }^{14}$. Only a charismatic leader like Aliyev could afford to take this step, which, undoubtedly, went far beyond a regulation by a regional leader: a powerful symbolic capital, which he was the only one of all Azerbaijani politicians of the time to have allowed him to perform this gesture. In essence, that was a call addressed to all Azeris living outside the Azerbaijani Republic to remember their "political motherland". This was although the first but already a very important symbolic act demonstrating not only the future change to the status of Azerbaijan in the world but also a change of the very rules of the political game which would now be played not in a space confined by an "iron curtain" but on a wide global scale.

The very prospect for conducting a purposeful policy in relation to the diaspora became a reality once Heydar Aliyev became president. Every year, since December 1993, the president's address to the Nation has turned into traditional address to the global community of Azeris living in a variety of places around the world. It was Heydar Aliyev who made the annual global address a habitual thing that actualises the idea that all ethnic Azeris belong to a united and joint 50 millions-strong ethnic community ${ }^{15}$. "On this remarkable day, I congratulate all Azeris of the world on the Day of Solidarity, and wish everyone successes in the name of an even brighter future for Azerbaijan and unity and solidarity of our people". ${ }^{16}$

However, main events of the diaspora policy took place in the 21 st century. As Aliyev put it, an important stage for the unification of Azeris took place on November 2001 - the $1^{\text {st }}$ Congress of Azeris of the World, timed to coincide with the $10^{\text {th }}$ anniversary of the appearance of independent Azerbaijan on the world map. His successor said that "it was after this congress that the State Committee for Work with Azeris Living in Foreign Countries was set up in Azerbaijan under Heydar Aliyev's decision. This committee carries out quite successful work to organize Azeri diaspora. The law on state policy

14 Regulation by the Supreme Assembly of the Naxcivan Autonomous Republic "On the day of solidarity and unity of Azeris of the world", dated 16 December 1991.

15 In fact, the very concept of united 50m-strong community was formulated at a far later stage.

16 See Bakinskiy Rabochiy, 01.04.1994 (newspaper in Baku, in Russian). 
connected with Azeris living abroad was adopted in 2002, which laid the legal basis of this movement. All these measures and all these steps are yielding fruit. Our compatriots in the world are getting organized and playing an increasingly more active role in the life of the countries they live in. certainly, on the one hand, this strengthens their position, and on the other, this strengthens the positions of the independent Azerbaijani Republic and multiplies its authority" ${ }^{17}$ As a logical continuation of the diaspora policy (at the $1^{\text {st }}$ congress it was decided to hold such events every five years), the $2^{\text {nd }}$ Congress took place on 2006. This congress renewed the members of the "Coordinating Council of Azeris of the World" which was created at the $1^{\text {st }}$ Congress. This Council comprises 109 people, 45 of whom permanently live abroad. The number one member of the Council is the current president, Ilham Aliyev.

The latest significant event is one of the first decrees that Azerbaijani President Ilham Aliyev signed after his re-election to the post in October 2008. This is the decree "On the establishment of the State Committee of the Azerbaijani Republic for Work with Diaspora", which was signed on 11.19.2008. Naturally, everything was confined to the mere renaming of the already existing "Commute for work with Azeris living abroad". However, the interesting thing is that the main declarative aim of this decree was to improve the structure of state management in Azerbaijan. In his speech at the $2^{\text {nd }}$ Congress of Azeris of the World, the current president re-affirmed his adherence to the diaspora policy which formed under his father. "Are we conducting our own foreign policy. And here, certainly, one can feel a great need for both your help and intensification in your overall activities. I have seen in the past few years that this work acquires coordinated forms - the work of the Foreign Ministry, the State Committee for Work with Azeris Living in Foreign Countries, Azeri diaspora bodies, events held in various countries, conferences, symposiums, other events connected with Azerbaijan - all this strengthens our positions and gives the world community true information about Azerbaijan"18.

\section{CONCLUSIONS}

It should be summarized that all attempts undertaken so far, as Anderson (1998: 44-45) put it, to construct, using the state apparatus, mathematics (statistics) and with the involvement of ethnic activists, an ethno-national Azeri diaspora as a collective subjectivity are still not producing much result. The disposition for a quantitative increase in the number of registered ethnic organizations acquires a key significance in the space of official discourse. In reality, basically quite a limited circle of ethnic activists mainly participate in their work. Having become partners of the authorities of their political homeland, they are given a status to represent the ethno-national community of a city, country, a part of the world... In this line of increasingly wider representations, the president of the political homeland now represents all "compatriots".

17 Ibid.

18 Azerbaijani president's speech at $2^{\text {nd }}$ Congress of Azeris of the world. Bakinskiy Rabochiy, $\mathrm{n}^{\circ} 48$, 03.17.2006. 
Implementing this project, the authorities prefer to cooperate with migrants that they view as having a status (ethnic activists, workers of science, culture and so forth). However, delegates of all possible congresses, forums and other collective events, represent, basically, themselves, and/or their personal interests or the interests of closest people to them (these are interests that are mainly connected to production of transnational business networks).

In reality, a significant part of Azeris abroad who do not want contacts with the embassy for different reasons (political refugees, illegal emigrants, etc.), is excluded from participation in the ethno-national community being constructed. Their presence in the official diaspora discourse is limited by statistics only. There is almost no intensive and successful interaction, and there will not be in the near future, among Iranian, Turkish and "Soviet" Azeris. The expanded cooperation of the ethnic organizations of Turks and "different" Azeris seems even less probable. On the contrary, ties with ethnic Jews, especially natives of Azerbaijan, are an important resource for arranging the activities of ethnic organizations.

Routine daily reminders in the media about a growth of successes of diasporabuilding acquire special significance for representing the ethno-national diaspora. The reality of "the Azerbaijan Diaspora" as a homogeneous and real group arises in the space of constantly increasing narratives both from the authorities of Azerbaijan (the president's appeals and statements, etc.), and from ethnic activists in emigration. This discourse construct is complemented by the imaginary statistics of the number of Azeris outside their political homeland as a millions-strong consolidated group acquiring features of being real against the background of a daily turn of news of events in the "diaspora".

So, behind the organizations there are only a handful of activists and their personal ambitions, behind statistics there are no real data, and the millions-strong consolidated ethno-national Azeri diaspora exists only as a discourse or, paraphrasing Irina Sandomirskaya, only when it is spoken about. At the same time, since 2001, when the symbolical $1{ }^{\text {st }}$ Congress of Azeris of the World took place, the political project of diasporabuilding has been acquiring features of a long-term arrangement and it cannot be ruled out that it may result in one or another degree of a successful building of a transnational community of Azeris or an ethno-political lobby in one or another country.

\section{References}

ANDERSON Benedict (1998) The Spectre of Comparisons: Nationalism, Southeast Asia and the World, London, Verso.

ANDERSON Benedict (1998) Imagined Communities: Reflections on the Origin and Spread of Nationalism, London, Verso.

BILLIG Michael (1995) Banal Nationalism, London, Sage.

BOURDIEU Pierre (2007) Sotciologiya sotcialnogo prostranstva, Moscow, Institute Experimentalnoi sotciologii.

BRUBAKER Rogers (1994) Nationhood and the national question in the Soviet Union and postSoviet Eurasia: An institutionalist account, Theory and Society, 23 (1), pp. 47-78. 
BRUBAKER Rogers (1996) Nationalism reframed: nationhood and the national question in the New Europe. Cambridge, Cambridge University Press.

BRUBAKER Rogers (2002) Ethnicity without groups, Archive Européenne de Sociologie, XLIII (2), pp. 163-89.

BRUBAKER Rogers (2005) The "Diaspora” Diaspora, Ethnic and Racial Studies, January, 28 (1), pp. 1-19.

COHEN Robin (1996) Diasporas and the nation-state: from victims to challengers, International Affairs, 72 (3), pp. 507-20.

DEMMERS Jolle (2005) Nationalism from without. Theorizing the role of diasporas in contemporary conflict, in T. Atabaki and S. Mehendale Eds., Central Asia and the Caucasus: Transnationalism and Diaspora, New York, Routledge, pp. 10-20.

FAIRCLOUGH Norman (1995) Critical Discourse Analysis, London, Longman.

HENRY Leroi, MOHAN Giles and YANACOPOULOS Helen (2004) Networks as Transnational Agents of Development, Third World Quarterly, 25 (5), pp. 839-855.

KING Charles and MELVIN Neil J. (1999-2000) Diaspora Politics: Ethnic Linkages, Foreign Policy, and Security in Eurasia, International Security, 24 (3), pp. 108-38.

KOLSTO P. (2001) Ykorenayushiesa Diaspori: Russkie v bivshix sovetskix respyblikax, Diaspori, 1, pp. 6-38.

KOSMARSKAYA N. (2002) Russkie Diaspori: Politicheskiye mifologii I realii massovogo soznaniya, Diaspori, 2, pp. 110-156.

MALAKHOV V. (2007) Ponayehali Tut... Ocherki o Natsionalizme, Rasizme i Kulturnom Pluralizme, Moscow, NLO.

MALAKHOV V. (2002) Preodolimo li etnotsentricheskoe mishleniye? in V. Voronkov, O. Karpenko and A. Osipov Eds., Rasizm v yazike sotsialnix nayk, Saint-Petersburg, pp. 9-22.

NIZNIK Marina (2003) The Russian Language as a Base Factor: The Formation of the Russian Community in Israel, in R. Münz and R. Ohliger Eds., Diasporas and Ethnic Migrants: Germany, Israel and Post-Soviet Successor States in Comparative Perspective, London, Portland, Frank Cass, pp. 355-369.

SAFRAN William (1991) Diasporas in Modern Societies: Myths of Homeland and Return, Diaspora, 1 (1), pp. 83-99.

SAFRAN William (2003) The End of "Normality": The Diasporization of Israel?, in R. Munz and R. Ohliger Eds., Diasporas and Ethnic Migrants: Germany, Israel and Post-Soviet Successor States in Comparative Perspective, London, Portland, Frank Cass, pp. 385-400.

SHEFFER Gabriel (2003) Diaspora Politics: At Home Abroad, Cambridge, Cambridge University Press.

SÖKEFELD Martin (2006) Mobilizing in transnational space: a social movement approach to the formation of Diaspora, Global Networks, 6 (3), pp. 265-84.

TISHKOV Valery (2003) Rekviyem po etnosy. Issledovaniye po sotsialno-uylturnoy antropologii, Moscow, Nauka. 


\title{
Post-Soviet Nation State as a Sponsor of Construction of the Ethno-National Diaspora: Azeri's Case
}

\author{
Sergey RUMYANSEV
}

\begin{abstract}
The policy of constructing an Azeri ethno-national diaspora started to be intensively implemented in the early $21^{\text {st }}$ century. However, the formation of this purposeful policy was preceded by various events that demonstrated a constantly increasing interest on the part of the state in ethnic Azeris living in various countries of the world. This paper presents the results of the research into the process of formation of diaspora politics in Azerbaijan and also analyses the aims and specifics of the mechanisms of its implementation. The first one, the discourse practice, refers to the discursive effect of truth within the context of which "diaspora" acquires the features of a true, large, joint and homogenous community united by common goals. The second is the bureaucratic practice of the production of a hierarchically structured and co-subordinated organization structure. The bureaucratization of social networks of Azeris in the world occurs in 2000-th years, as a result of which an organizational structure of diaspora is constructed. This structure is uniform from local organisation up to those which represent all ethnic communities with "a Minister for the Diaspora" at its head and subordinated directly to the pan-Azeri president.
\end{abstract}

\section{L'État-nation postsoviétique comme soutien de la construction de la diaspora ethno-nationale : le cas azerbaïdjanais}

\section{Sergey RUMYANSEV}

La politique de constitution d'une diaspora ethno-nationale azeri commença à voir le jour de façon significative au début du XXIe siècle. Cependant, cette politique raisonnée fut précédée de différents évènements qui ont fait apparaitre l'intérêt croissant de l'État pour les personnes d'ethnie azeri vivant dans différents pays du monde. L'auteur donne les résultats d'une recherche sur le processus de formation de politiques en faveur de la diaspora en Azerbaïdjan. Il en analyse aussi les buts et les mécanismes spécifiques. Le premier aspect renvoie aux effets de discours de vérité dans un contexte où la « diaspora » acquiert les traits d'une vaste communauté unifiée et homogène, unie par des buts communs. La seconde démarche relève de mécanismes bureaucratiques de co-production d'une structure organisationnelle hiérarchique. La bureaucratisation des réseaux sociaux azeris dans le monde intervient au cours des années 2000, avec pour conséquence la constitution d'une structure organisationnelle de la diaspora. Celle-ci est uniforme, du niveau local jusqu'à l'institution qui représente toutes les communautés ethniques, avec à sa tête un « Ministère des Diasporas », sous la tutelle du président pan-azeri.

\section{El estado-nación postsoviético como promotor de la construcción de une diáspora etnonacional: el caso azerbaiyano.}

\section{Sergey RUMYANSEV}

La política para la construcción de una diáspora etnonacional azerbaiyana ha sido implementada de manera intensiva a principios del siglo 21. Sin embargo, la elaboración de esta política fue precedida por varios acontecimientos que demostraron el interés cada vez más creciente del estado hacia la etnia azerbaiyana dispersada en diferentes países del mundo. Este informe presenta 
los resultados de la investigación sobre el proceso de elaboración de las políticas relativas a la diáspora en Azerbaiyán. Analiza también los objetivos y las especificidades de los mecanismos de su puesta en práctica. El primero, el ejercicio del discurso, remite al efecto discursivo de la verdad en el contexto del cual la diáspora adquiere los rasgos de une verdadera comunidad: amplia, homogénea y unida por un objetivo común. El segundo ejercicio concierne la burocratización de la producción de una organización co-subordinada y estructurada de manera jerárquica. La burocratización de redes sociales azerbaiyanas en el mundo empezó en los años 2000, generando la construcción de una estructura organizacional de la diáspora. Esta estructura tanto se refiere a una organización local como a una organización que representa a todas las comunidades étnicas. Tiene a su cabeza un ministerio de la Diáspora que depende directamente del presidente pan azerbaiyano.

\section{Постсоветское Национальное государство как спонсор конструирования этно-национальной диаспоры. На примере Азербайджанцев. Сергей РУМЯНЦЕВ}

Политика конструирования азербайджанской этно-национальной диаспоры стала активно реализовываться в период начала 2000-х годов. Формированию этой целенаправленной политики предшествовали различные события, которые демонстрировали постоянно возрастающий интерес государства к этническим азербайджанцам, живущим в разных странах мира. В данной статье представлены результаты исследования процесса формирования диаспоральной политики в Азербайджане, а также анализируются цели и специфика механизмов ее реализации. По мнению автора, механизмы реализации политического проекта конструирования диаспоры, в целом, сводятся к двум важнейшим и взаимосвязанным практикам. Первая - это дискурсивная практика. Рутинное, практически ежедневное напоминание в СМИ о деятельности «азербайджанской диаспоры», постоянные интервью этнических активистов, чиновников и различного рода общественных деятелей, рассказывающих о реализации проекта конструирования диаспоры. Вторая - это бюрократическая практика производства иерархически структурированной и соподчиненной организационной структуры. Единая от низовых организаций до тех, которые представляют уже все этнические общины структура, как бы построенная по принципу государственной вертикали власти представляется простой, понятной, прозрачной и удобной для контроля. Во главе этой структуры как бы стоит «министр диаспоры», подчиненный уже, непосредственно, всеазербайджанскому президенту. 